administrative struggles of the twentieth century. Marshall took these in his stride, and, I think, none of our Indian colleagues, many of whom were his pupils, would deny that the Archæological Department is what it is to-day through the care and foresight of his early planning. Some have criticized his methods of excavation. Marshall was too philosophical and critical to think that any method had absolute validity or that any work of his was done once and for all. He was himself courteous and generous especially to younger men. Though aware that his achievement was no mean one, he shared his generation's distaste for " window dressing ".

Marshall devoted his life to India, and loved the country and its people. The Governments of India and Pakistan recognised his devotion by making it possible for him to continue his work in his retirement. The fruit of their wise generosity is his last book, "Buddhist Art in Gandhara," now in the press.

Douglas Barrett.

\title{
Arshak Safrastian
}

Arshak Safrastian, for many years a member of the Society, died on 25th September, 1958, at the age of seventy-two. A specialist in Armenian studies, he had in later years interested himself in Urartian and Hurrian themes. Much of his work appeared in Armenian language periodicals; but he was editor of the Armenian monthly Massis, published in London between the wars, and in that journal he provided in English many useful summaries of contemporary Armenian research. He wrote on "Armenian History" for the 14th edition of the Encyclopaedia Britannica and, in 1948, published a short book, Kurds and Kurdistan. His more scholarly work in English included a paper on "The Hurri-lands" in Georgica, 4/5 (1937) and " The Land of Hurri in the Armenian Language and Literature " read at the XXI International Congress of Orientalists in Paris in 1948. His magnum opus in English on the Hurri runs into several hundred pages of typescript and is the result of many years of research. It is hoped that this work may be published.

Arshak Safrastian was born in the ancient city of Van, of a large and patriarchal family engaged in farming and trade. Before the First World War he was H.B.M. Acting Vice-Consul in Bitlis. During 1915-16, he served in an Armenian unit of the Russian 
Caucasian Army. In 1919, when just over thirty, he was nominated a member of Nubar Pasha's delegation to the Peace Conference in Paris. Afterwards, Safrastian settled in London, where he lived for nearly forty years, an active and lively participant in the affairs of the Armenian community and an assiduous reader at the British Museum. He had many English friends who remember him with affection for his resolute courage, his unflagging devotion to scholarship and his cheerful, happy spirit. This man of farming stock from an almost biblical background had moulded out of the vicissitudes of his life an inner harmony which he irradiated in a harassed world. He was a very great human being.

$$
\text { W. E. D. Allen. }
$$

\section{KOREA BRANCH OF THE ROYAL ASIATIC SOCIETY}

The latest volume of the Transactions of this Society is devoted almost entirely to a paper by the Rev. Richard Rutt on the Sijo, a form of Korean poetry hitherto not described in English. Applications for the Transactions or for membership of the Society should be addressed to the Corresponding Secretary (Colonel A. E. E. Mercer), British Embassy, 4 Chong Dong, Sudaemoon Ku, Seoul, Korea. 